\title{
A Cross Sectional Evaluation of Patients with Ostomy in Turkey
}

\section{Türkiye'de Stoma Açılan Hastaların Kesitsel Değerlendirilmesi}

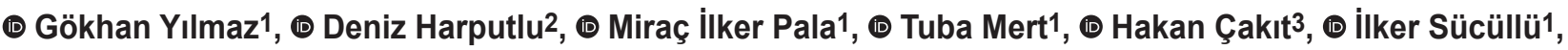 \\ (1) Ayhan Kuzu4
}

${ }^{1}$ İstanbul Medipol University Faculty of Medicine, Department of General Surgery, İstanbul, Turkey

${ }^{2}$ Ankara University Faculty of Nursing, Stoma Care Nurse, Ankara, Turkey

3ístanbul Sultan 2. Abdülhamid Han Training and Research Hospital, Clinic of General Surgery, İstanbul, Turkey

${ }^{4}$ Ankara University Faculty of Medicine, Department of General Surgery, Ankara, Turkey

\section{HIIIII| ABSTRACT}

\begin{abstract}
Aim: Despite recent technological developments, a stoma formation is needed for the treatment of many diseases, especially in colorectal surgery. Due to the radical principles of cancer treatment, the number of patients living with stoma is increasing. However, there is no study that quantitatively evaluates the stoma patients nationally. In this study, it was aimed to retrospectively evaluate the demographic data, indications, preferred types of stoma and the outcomes of patients who had a stoma formation in our country in the last three years.

Method: In our country, there are 3 companies that operate in the field, provide materials for $95 \%$ of stoma patients. The data of patients who had a stoma between 2017 and 2019 were collected from these companies retrospectively by protecting personal privacy of patients. The distribution of indications and type of stoma acording to indications were determined. Average age, stoma closure rates and mortality rates were calculated. All data are presented as numbers and percentages and categorical variables are shown as median (minimum-maximum), continuous variables are shown as \pm standard deviation.

Results: The most common indication for stoma creation was colorectal malignancy (58.4\%) and followed by mechanical bowel obstructions (29.6\%). Other malignancies (4.16\%), inflammatory causes (4.58\%), traumatic causes (1.88\%) and congenital anomalies ( $1.17 \%)$ constituted a total of $11 \%$ stoma indications. It was observed that. ostomies opened due to colorectal malignancy,were closed in $40 \%$ of patients with loop ileostomy, $30.1 \%$ of patients with loop colostomy, and only $13 \%$ of patients with end colostomy.

Conclusion: We aimed to obtain a national perspective by evaluating the patients who had a stoma in the last 3 years and to show up the distribution of stoma formation indications in our country. We have determined the demographic data of patients with stoma and calculated the stoma closure and mortality rates according to stoma types. Although this study is a cross-sectional evaluation of patients in the whole country, weak point of our study is there are deficiencies in our evaluation due to the lack of retrospective data. We think that prospective studies should be planned by detailing subgroups.
\end{abstract}

Keywords: Ileostomy, colorectal malignancy, colostomy, stoma

\section{IIIIIIIII| ÖZ}

Amaç: Ülkemizde stomalı bireyleri niceliksel olarak inceleyen çalışma henüz bulunmamaktadır. Bu çalışmada ülkemizde son üç yıl içinde stoma açılmış olan hastaların demografik verilerinin, endikasyonlarının, tercih edilen stoma tiplerinin ve hastaların akıbetlerinin retrospektif olarak değerlendirilmesi amaçlanmıştır.

Yöntem: Ülkemizde stoma alanında faaliyet göstermekte olan ve stoma hastalarının stoma malzemelerini sağlayan 3 firmanın 2017-2019 yılları arasında, malzeme temin ettiği stoma hastalarının bilgileri, kişisel verilerin gizliliği kurallarına dikkat edilerek retrospektif olarak derlenmiştir. Endikasyona göre hastalara hangi tip stoma açıldığı, bu hastaların cinsiyete göre dağılımı (minimum-maksimum), yaş ortalamaları, stoma kapatılma oranları, ölüm oranları hesaplanmıştır.

Bulgular: En sık stoma oluşturma endikasyonunun kolorektal malignite olduğu ve tüm stomaların \%58,4'ünü oluşturduğu görüldü. Bunu mekanik barsak tıkanıklıkları $(\% 29,6)$ takip etmekte idi. Diğer maligniteler $(\% 4,16)$, enflamatuvar sebepler $(\% 4,58)$, travmatik sebepler $(\% 1,88)$ ve doğumsal

Address for Correspondence/Yazışma Adresi: Gökhan Yılmaz, MD,

İstanbul Medipol University Faculty of Medicine, Department of General Surgery, İstanbul, Turkey

E-mail: drgokhanylmz@gmail.com ORCID ID: orcid.org/0000-0003-0889-9586

Received/Geliş Tarihi: 28.10.2020 Accepted/Kabul Tarihi: 23.12.2020

${ }^{\circ}$ Copyright 2021 by Turkish Society of Colon and Rectal Surgery

Turkish Journal of Colorectal Disease published by Galenos Publishing House. 
anomaliler $(\% 1,17)$ toplamda yaklaşı \%11 oranında stoma açılmasına endikasyon oluşturmaktaydı. Kolorektal malignite nedeni ile açılan stomalar değerlendirildiğinde loop ileostomi uygulanan hastların \%40'ının, loop kolostomi uygulanan hastaların \%30,1'inin stoması kapatılabilmişken, uç kolostomi uygulanan hastaların sadece \%13'ünün stomasının kapatıldığı görülmüştür.

Sonuç: Ülkemizde son 3 yıl içinde stoma açılmış olan hastaları değerlendirerek ulusal anlamda geniş bir perspektif elde etmeyi amaçladık. Stoma ile yaşamak durumunda olan hastaların demografik verilerini, kaçının stomasının kapatılabildiğini ve stoma tiplerine göre stoma kapatılma ve ölüm oranlarını tespit ettik. Stomalı bireylerin analizini gerçekleştirdiğimiz bu çalışma, ulusal anlamda gerçekleştirilen ilk çalışma olmasına rağmen, retrospektif verilerdeki eksiklikler nedeni ile değerlendirmemizde yetersizlikler mevcuttur. Alt grupların detaylandırılarak, prospektif özellikte çalışmaların planlanması gerektiğini düşünüyoruz.

Anahtar Kelimeler: İleostomi, kolon kanseri, kolostomi, stoma

\section{Introduction}

The word "ostomy" is derived from the word "stoma" which means "mouth" in ancient Greek. Medically, it is an artificial opening where a luminal organ in the abdomen is mouthed to the abdominal wall by surgical intervention. It is frequently used in conditions such as inflammatory bowel diseases, trauma, congenital anomalies, mechanical bowel obstructions, and especially colorectal cancer. ${ }^{1,2}$ Stomas can be permanent or temporary according to their indication, or they are named as "end" or "loop" according to the type of anastomosis created between the intestine and the abdominal wall. The most common types of stoma created are transverse colostomy and ileostomy. ${ }^{3}$

Anastomotic leakage is a serious problem in colorectal surgery. It is seen in approximately 10-15\% of patients. ${ }^{4}$ It has been reported that anastomotic leakage after rectum resection results in mortality with a probability of $6-22 \% .^{5}$ Many studies have shown that diverting stomata do not reduce the rate of anastomotic leakage. ${ }^{6}$ However, stomata accelerate healing by preventing local and systemic septic reactions in case of a clinical leak. ${ }^{7}$ When comparing protective ileostomy created after distal colorectal resection and colostomy, ileostomy was found to be superior in terms of infection, hernia and complications related to stoma. ${ }^{8}$ In a multi-center randomized study, it has been shown that a stoma that is planned to be temporary has a $19 \%$ chance of being permanent. ${ }^{9}$ Although the chance of stoma closure depends to some extent on the urgency of ostomy formation; risk factors such as advanced age ( $>65$ years of age), major comorbidity (American Society of Anesthesiologists score $>2$ ), surgical complications and advanced tumor are emphasized in the literature. ${ }^{10,11}$

Our study aimed to obtain quantitative data by reviewing information such as which type of stoma general surgeons preferred according to indications, stoma closure rates, number of patients with stoma and death. Especially in accordance with the radical treatment principles of patients with cancer, the number of patients who survive with stoma is gradually increasing. However, it is not possible to determine the number of patients with stoma at any time, as a different number of stomata are created and closed every day. ${ }^{12}$ With the advancement of information and technology use, the number of studies in this field is increasing. Systematic reviews have been published in the world literature on issues such as stoma and peristomal complications, morbidity, and stoma care and management. ${ }^{13,14,15,16}$ However, there is no study examining individuals with stoma quantitatively in Turkey yet.

In this study, we aimed to retrospectively evaluate the demographic data, indications, preferred types of stoma and the outcomes of patients who had a stoma in our country in the last three years as the "Stoma Study Group" established within the Turkish Society of Colon and Rectal Surgery. With the results to be obtained from these data, it was aimed to reveal the tendencies of surgeons working in our country about stoma, to determine the distribution of patients in our country by evaluating the number of patients who needed stoma annually, and to better organize the training/service needs in this field.

\section{Method}

This study was approved by the İstanbul Medipol University Non-invasive Ethics Committee (date: 26.11.2020, decision no: 863). Age, gender, surgery dates, surgery indications, stoma types (loop stoma, end stoma, colostomy, ileostomy, etc.) of the patients who were provided stoma materials between 2017-2019 were requested in Microsoft Excel® format without address, telephone number and identity information to protect personal data from 3 companies operating in the field of stoma in our country. Data on a total of 28,316 individuals with stoma were accessed and screened by a single investigator. Of the patients 3,701 were excluded from the study because they received stoma service due to urostomy. Of the remaining 24,615 patients, 1,516 were excluded from the study because of missing information on their diagnoses and 542 were excluded because of missing information on which type of stoma was created, and the evaluation was made on a total of 22,557 patients. Stomata created with the diagnosis of colon cancer, rectal cancer, congenital anorectal anomalies, urological and gynecological 
malignancies, benign inflammatory diseases, trauma and mechanical bowel obstruction were classified according to stoma type and years (Table 1). Indications such as diverticular disease, inflammatory diseases such as ulcerative colitis and Crohn's colitis, enterocutaneous fistula, enteroenteral fistula, large pressure sores, volvulus, and intestinal obstruction due to adhesion were evaluated as benign diseases. Stomata created due to urological and gynecological malignancies were evaluated as malignant diseases. According to the indication, which type of stoma was created in the patients (loop ileostomy, end ileostomy, loop colostomy, end colostomy), distribution of these patients by gender, mean age, stoma closure rates, and death rates were calculated. All data are given as numbers and percentages.

\section{Results}

When we evaluated patients who had stoma between January 2017 and December 2019 in Turkey, it was seen that $8,260(36.6 \%)$ patients had stoma in 2017, 7,261 (32.2\%) in 2018 and $7,036(31.2 \%)$ patients in 2019. Of the patients $13,546(60 \%)$ were male, 9,011 (40\%) were female. When the distribution of patients was examined according to the type of stoma created, it was determined that $32.4 \%(7,297)$ had loop colostomy, 32\% $(7,218)$ loop ileostomy and $27 \%$ $(6,272)$ end colostomy. The least created ostomy type was $7.8 \%(1,770)$ end ileostomy $(7.8 \% / 1,770)$. It was found that within 3 years, $27.8 \%(6,274)$ of patients with stoma had their stoma closed, and $17.3 \%(3,924)$ died (Table 1).
It was observed that the most common indication for stoma creation was colorectal malignancy (13,198 patients) and constituted $58.4 \%$ of all stomata. Mechanical intestinal obstructions (29.6\%) followed colorectal malignancy. Other malignancies (4.16\%), inflammatory causes (4.58\%), traumatic causes (1.88\%) and congenital anomalies (1.17\%) were indications of stoma creation at a total rate of approximately $11 \%$ (Table 2). When we evaluated these numbers according to years, it was seen in Table 2 that the number of stoma creation in each indication tended to decrease in three years.

When we evaluated the colorectal malignancies, we found that 4,886 (37\%) patients had loop colostomy, 3,609 (27.3\%) patients loop ileostomy, 3,832 (29\%) patients end colostomy, and 871 (6.5\%) patients underwent end ileostomy. It was observed that stoma was closed in $40 \%$ of patients who underwent loop ileostomy and 30.1\% of patients who underwent loop colostomy, while stoma was closed in only 13\% of patients who underwent end colostomy. When the mortality rates of colorectal malignancies with stoma were evaluated according to the type of stoma, it was determined that $15.1 \%$ of patients with loop ileostomy, $17.4 \%$ of patients with end ileostomy, $21.1 \%$ of patients with loop colostomy and $19.3 \%$ of patients with end colostomy died. Three-year total closure rate of stoma in patients with colorectal malignancy was $27.8 \%$, while the rate of patients who died was $18.9 \%$. The three-year total closure rate of stoma in male patients was $27.3 \%$, and the rate of patients who died was $17 \%$. In women, these rates

Table 1. Demographic data

\begin{tabular}{|c|c|c|c|}
\hline & & Stoma number & $\%$ \\
\hline \multirow[t]{2}{*}{ Gender } & Male & 13,546 & 60 \\
\hline & Female & 9,011 & 40 \\
\hline \multicolumn{2}{|l|}{ Age } & \multicolumn{2}{|l|}{ Mean: 57.2} \\
\hline \multirow{2}{*}{ Distribution by years } & 2017 & 8,260 & 36.6 \\
\hline & & 22,557 & \\
\hline \multirow{2}{*}{ Stoma type } & Loop ileostomy & 7,218 & 32 \\
\hline & End ileostomy & 1,770 & 7.8 \\
\hline \multicolumn{2}{|l|}{ Ex } & 3,924 (mean age: 63.3 ) & 17.3 \\
\hline
\end{tabular}


were determined as $28.5 \%$ and $22 \%$, respectively (Table 3 ). It was observed that stoma was created in 1,035 (4.58\%) patients due to benign inflammatory reasons, 260 (25.1\%) of these patients were subjected to stoma closure procedure, and 100 (9.6\%) patients died. It was found that 106 (24.9\%) of 425 (1.88\%) patients with stoma created due to trauma were closed, while 28 (6.5\%) patients died. In mechanical bowel obstruction, which was the second most common cause of stoma creation after colon cancer, it was found that the stoma of $29.6 \%$ of the patients was closed within 3 years, and $16.4 \%$ of them died. Only mortality rate in advanced gynecological and urological malignancies was higher (18.5\%) than stoma closure rate (15.2\%) (Table 4).

Table 2. Distribution of stoma indications by years

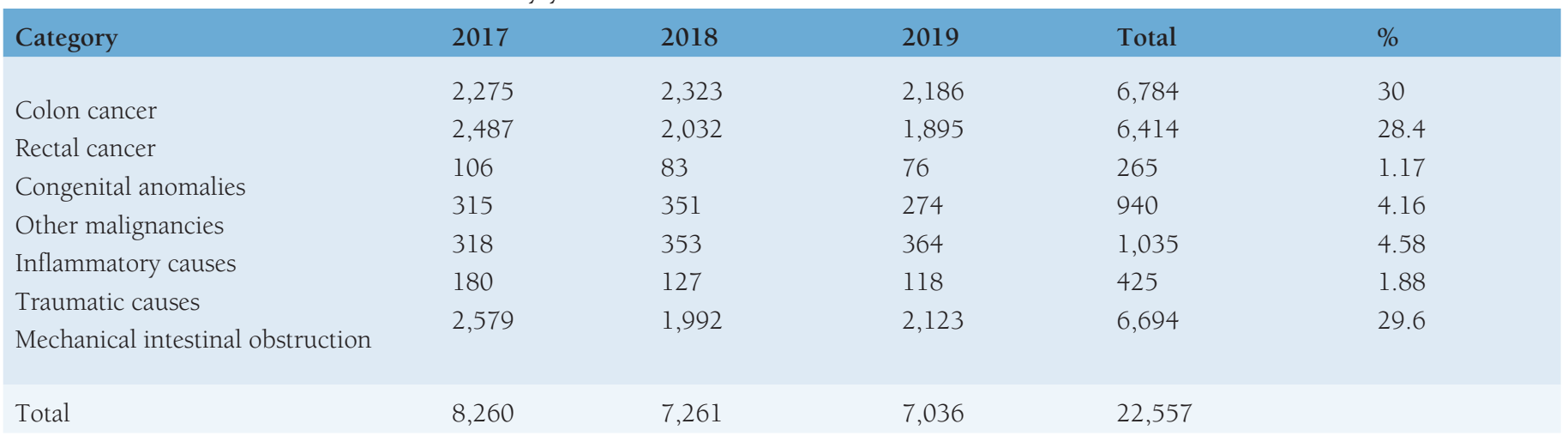

Table 3. Stoma closure of colorectal malignancies and number of deaths

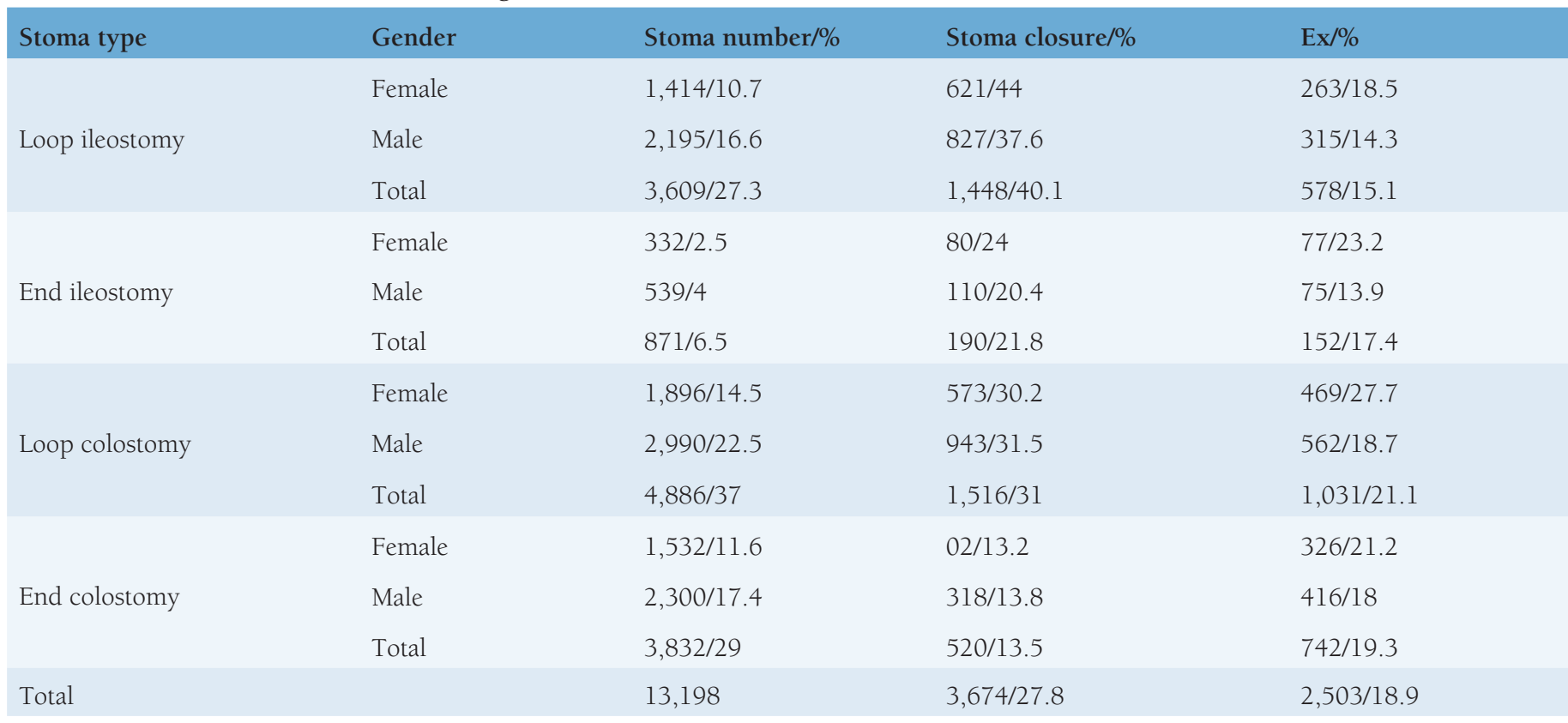

Table 4. Stoma closure and number of deaths in patients with stoma created except for colorectal malignancy

\begin{tabular}{llll} 
Indication & Stoma number/\% & Stoma closure/\% & Ex/\% \\
\hline Congenital anomalies & 265 & $104 / 39.2$ & $17 / 6.4$ \\
Benign inflammatory causes & 1,035 & $260 / 25.1$ & $100 / 9.6$ \\
Traumatic causes & 425 & $106 / 24.9$ & $28 / 6.5$ \\
Mechanical bowel obstruction & 6,694 & $1,987 / 29.6$ & $1,102 / 16.4$ \\
Other malignancies & 940 & $143 / 15.2$ & $174 / 18.5$ \\
Total & 9,359 & $2,600 / 27.7$ & $1,421 / 15.1$
\end{tabular}




\section{Discussion}

In this cross-sectional study, we aimed to reveal the tendencies of surgeons working in our country about stoma, and to determine the distribution in our country by evaluating the number of patients who needed stoma annually. We aimed to create a national prediction by determining the percentage of deaths of patients with stoma, stoma closure rate, stoma indications and stoma types. Although it is not prospective, we think that this study, which is a crosssectional evaluation of our country, is important in terms of providing information to healthcare professionals working in the field of general surgery.

When we evaluated the patients who had stoma from January 2017 to December 2019, we saw that stoma was created in 9,438 patients annually. When we excluded patients with urostomy, the average number of stoma created was 8,205 per year, and it was shown that the most important cause of stoma creation was colorectal cancer.

Since there is no comprehensive study on this subject in our country, data on the number of patients with stoma is insufficient. In our study, when we reviewed the data of 3 companies operating in our country that provided materials to patients with stoma, we saw that the number of stoma created in 3 years was 28,316. The number of patients with stoma in the world is not clearly known. The German Ostomy Society, a charity organization, acknowledges that it will not be possible to measure the actual number of patients with ostomy at any given time. ${ }^{17}$ It was reported that approximately 700,000 individuals from all age groups had stoma (ileostomy, colostomy or urostomy) in the member countries of the European Union Commission in 2011. ${ }^{18}$ In China, it is stated that approximately 1 million people have permanent colostomy. ${ }^{19}$ Different data and future predictions stand out in the ostomy report published by the European Ostomy Association in 2017, according to the countries. According to this report, the number of patients with ostomy in Germany is given as approximately 150,000 and it is stated that these numbers are not accurate. ${ }^{20}$ Data from Denmark and England show that 2,000 people per million in Northern Europe currently live with stoma. ${ }^{21,22}$ It is estimated that the number of patients with stoma in Spain, of which population is 47 million, is approximately $70,500 .{ }^{23}$ It is thought that 500,000 people have stoma in the United States and 120,000 new surgeries are performed each year. The United Ostomy Associations of America predicts that this number will grow at an annual rate of 3\%. ${ }^{24}$ Although an increase in the number of stomata created every year in the United States was expected, it was determined that 8,260 stomata were created in 2017, 7,261 in 2018 and 7,036 in 2019 in our country, and it was observed that the number of patients with stoma creation tended to decrease every year. In our study, the average age of patients with stoma was 57.25. It was stated that the average age of patients with a stoma in the United States of America is $68 .{ }^{24}$ According to the data published by the European Ostomy Association, 46,000 of 70,500 patients with stoma in Spain were over the age of 45 and half of them were over 65 years old. ${ }^{23}$ We see that the average age of individuals with stoma in our country is low compared to the United States of America and European countries. Since the average age of patients with stoma is low in our country, the necessity to increase the quality of life of patients is more critical for our country, which has young patient polpulation with stoma.

In our study, $58.4 \%$ of patients with stoma were operated due to colorectal malignancy, while this rate was higher in the Netherlands with $67 \%$. The rate of stoma (41.6\%) created for reasons other than malignancy such as trauma, congenital anomaly and inflammatory diseases was found to be higher in our study compared to the Netherlands (33\%). ${ }^{25}$ According to GLOBOCAN 2018 (Estimated world cancer incidence, deaths and frequency) data of the International Agency for Research on Cancer-IARC; colorectal cancer was the third most common cancer among men and women in the world, and more than half (55\%) of colorectal cancers were seen in developed countries. ${ }^{26}$ In our study, we saw that there were 6,694 patients who were operated due to mechanical intestinal obstruction, although the rate of stoma created due to colorectal cancer was lower compared to European countries. It was not known how many of these patients who had a stoma due to mechanical bowel obstruction were due to colorectal malignancy. We could say that the number of patients with stoma created due to colorectal malignancy seemed low (58.4\%) for this reason in our study. However, considering that some of the patients with stoma created due to mechanical bowel obstruction were created due to colorectal malignancy, we could say that the data in our study were compatible with the literature.

It was observed that $60 \%$ of 22,557 patients included in our study had colostomy and $40 \%$ had ileostomy or jejunostomy. Loop ileostomy, end ileostomy, loop colostomy and end colostomy were performed on the patients, and the rates were found to be $32 \%, 7.8 \%, 32.4 \%$ and $27.8 \%$, respectively. However, we could not find any data about whether the created stomata were temporary or permanent. Considering the colorectal malignancies, it was determined that $40 \%$ of the patients who underwent loop ileostomy and $30.1 \%$ of the patients who underwent loop colostomy were able to be closed, while the stoma of only 13\% of the patients who underwent end colostomy was closed. When the mortality rates of colorectal malignancies with stoma were evaluated according to the type of stoma, no significant difference was 
found. There was no significant difference in stoma closure and mortality rates in male and female patients according to the type of stoma and indications. However, apart from congenital anomalies, we could say that the closure rates of stomata due to benign causes were much lower than colorectal malignancy (Table 4).

The 2-month cost of a patient with stoma in our country to the Social Security Institution has been determined as 491 TL. The annual stoma care cost of a patient with stoma is approximately 3,000 TL. ${ }^{27}$ However, most of the patients use a more comfortable and high quality stoma model by paying additional fees, and it is thought that the cost is much higher than expected throughout the country. As in all European countries and the United States of America, the total number of patients with stoma is not clearly known in our country. According to the data we have collected, stoma is created in an average of 9,438 patients annually in our country and the cost of stoma in our country increases by 30 million Turkish Liras each year. ${ }^{28}$ Although the number and cost of patients whose stoma expenses are paid by private health insurance or who is without insurance are not known, it is possible to predict that the costs we give may be higher. When compared with Europe, it is seen that the cost of stoma per person is approximately the same as in our country. ${ }^{24}$

The history of cancer registry activities in Turkey is not very long. With the introduction of mandatory cancer notification, the "Cancer Control Department" was established in 1983 with the Legislative Decree No. 181 to carry out cancer registration activities. One of the main duties of the Cancer Control Department is to collect qualified cancer records in a reliable and accurate manner. Looking at the picture on a global scale, Hamburg Cancer Registration Unit was established in 1926. The cancer registry in Slovenia has been publishing incidence, prevalence and survival rates in the Slovenian population since 1950. As these examples showed, cancer registry activities started in the early 1900s in many developed countries on a global scale. In Turkey, the collection of cancer data was started in 2000 with the "Cancer Registration Center Regulation". For this reason, we think that efforts to establish a strong registry system, which is the first step of cancer control in our country, are insufficient. Turkey is a member of international organizations such as International Agency for Research on Cancer (IARC), The Middle East Cancer Consortium, European Network For Cancer Registries and Union for International Cancer Control. We would like to emphasize the importance of attending congresses and meetings organized annually by these organizations on cancer registration. We think that obtaining accurate cancer data, which we consider to be the most important stage of the cancer control program, should be considered more important. Although serious improvements have been made in the quality of our data, we can say that there is not an adequate registry system. The data of patients who have to live with stoma should be recorded and cost analysis should be made. We believe that with the improvement in the registry system, it is necessary to follow the patients for whom the stoma closure procedure can be performed and to direct them to reference centers, both to increase patient comfort and to reduce stoma care costs nationally.

\section{Conclusion}

In our study, we aimed to obtain a national perspective by evaluating the patients who had a stoma in the last 3 years in our country. As the "Stoma Study Group" established under the roof of the Turkish Colon and Rectum Surgery Association, this study, in which we analyzed individuals with stoma, had the distinction of being the first nationally conducted study. There were inadequacies in our evaluation due to the deficiencies in the retrospective data, and this constituted the limitation of our study. It should be planned to carry out prospective studies by detailing the subgroups.

\section{Ethics}

Ethics Committee Approval: İstanbul Medipol University Non-invasive Ethics Committee (decision no: 863/date: 26/11/2020).

Informed Consent: Retrospective study.

Peer-review: Externally peer reviewed.

\section{Authorship Contributions}

Surgical and Medical Practices: I.S., A.K., Concept: G.Y., D.H., M.İ.P., H.Ç., İ.S., A.K., Design: G.Y., D.H., M.İ.P., T.M., H.Ç., İ.S., A.K., Data Collection or Processing: G.Y., D.H., T.M., H.Ç., İ.S., A.K., Analysis or Interpretation: G.Y., D.H., M.İ.P., H.Ç., İ.S., A.K., Literature Search: G.Y., D.H., T.M., H.Ç., İ.S., A.K., Writing: D.H., İ.S., A.K.

Conflict of Interest: No conflict of interest was declared by the authors.

Financial Disclosure: The authors declared that this study received no financial support.

\section{References}

1. Kann BR, Cataldo TE, Early stomal complications, Clin Colon Rectal Surg 2002;15:191-198.

2. Butler DL. Early postoperative complications following ostomy surgery. J Wound Ostomy Continence Nurs 2009;36:513-519.

3. Caricato M, Ausania F, Ripetti V, Bartolozzi F, Campoli G, Coppola R. Retrospective analysis of long-term defunctioning stoma complications after colorectal surgery. Colorectal Dis 2006;9:559-561.

4. Buchs NC, Gervaz P, Secic M, Bucher P, Mugnier-Konrad B, Morel P: Incidence, consequences, and risk factors for anastomotic dehiscence after colorectal surgery: a prospective monocentric study. Int J Colorectal Dis 2008;23:265-270. 
5. Rullier E, Laurent C, Garrelon JL, Michel P, Saric J, Parneix M: Risk factors for anastomotic leakage after resection of rectal cancer. Br J Surg 1998;85: 355-358.

6. Vignali A, Fazio VW, Lavery IC, Milsom JW, Church JM, Hull TL, Strong SA, Oakley JR. Factors associated with the occurrence of leaks in stapled rectal anastomoses: a review of 1,014 patients. J Am Coll Surg 1997; 185:105-113.

7. Pakkastie TE, Luukkonen PE, Järvinen HJ. Anastomotic leakage after anterior resection of the rectum. Eur J Surg 1994;160:293-297.

8. Tilney HS, Sains PS, Lovegrove RE, Reese GE, Heriot AG, Tekkis PP. Comparison of outcomes following ileostomy versus colostomy for defunctioning colorectal anastomoses. World J Surg 2007;31:1142-1151.

9. Den Dulk M, Smit M, Peeters KC, Meershoek-Klein Kranenbarg E, Rutten HJT, Wiggers T, Putter H, van de Velde CJH, Dutch Colorectal Cancer Group. A multivariate analysis of limit - ing factors for stoma reversal in patients with rectal cancer entered into the total mesorectal excision (TME) trial: a retrospective study. Lancet Oncol 2007;8:297-303.

10. Sier MF, van Gelder L, Ubbink DT, Bemelman WA, Oostenbroek RJ. Factors affecting timing of closure and non-reversal of temporary ileostomies. Int J Colorectal Dis 2015;30:1185-1192

11. Zhou X, Wang B, Li F, Wang J, Fu W. Risk factors associated with nonclosure of defunctioning stomas after sphincter-preserving low anterior resection of rectal cancer: a meta-analysis. Dis Colon Rectum 2017;60:544554

12. Ambe PA, Kurz NR, Nitschke C, Odeh SF, Möslein G, Zirngiblarch H. Intestinal ostomy:classification, indications, ostomy care and complication management. Deutsches Ärzteblatt International 2018;115. doi: 10.3238/ arztebl.2018.

13. Danielsen AK, Burcharth J, Rosenberg J. Patient education has a positive effect in patients with a stoma: a systematic review. Colorectal Dis 2013;15:276-283

14. Shabbir J, Britton DC. Stoma complications: a literature overview. Colorectal Dis 2010;12:958-964.

15. Chow A, Tilney HS, Paraskeva P, Jeyarajah S, Zacharakis E, Purkayastha S. The morbidity surrounding reversal of defunctioning ileostomies: a systematic review of 48 studies including 6,107 cases. Int J Colorectal Dis 2009;24:711723. doi: 10.1007/s00384-009-0660-z.

16. Recalla S, English K, Nazarali R, Mayo S, Miller D, Gray M. Ostomy care and management: a systematic review. J Wound Ostomy Continence Nurs 2013; $40: 489-500$

17. Die ILCO in Zahlen: Eine Übersicht. Last Accessed Date: 18.11.2017. Available from: www.ilco.de/verband/die-ilco-in-
18. Eucomed Medical Technology. Eucomed Background Paper, Access to Ostomy Supplies and Innovation: Guiding Principles for European Payers 2012. Available from: https://www.medtecheurope.org/wp-content/ uploads/2015/09/2002012_MTE_Access-to-Ostomy-Supplies-andInnovation-Guiding-Principles-for-European-Payers_Backgrounder.pdf

19. Luo BJ, Qin HY, Zheng MC. Correlation between social relational quality and hope among patients with permanent colostomies. International J Nurs Sci 2014;1:405-409.

20. Country Report to the European Ostomy Association EOA 2017 (German Ostomy and Colorectal Cancer Association). Available from: https:// ostomyeurope.org/wp-content/uploads/2017/10/2017_Deutsche-ILCO_ country_report.pdf

21. Country report from the Danish ostomy association COPA 2014 - 2017 Available from: https://ostomyeurope.org/wpcontent/uploads/2017/10/ Country_report_COPA_Denmark_2017.pdf

22. Report for EOA Meeting, Copenhagen, October 2017 Available from: https://ostomyeurope.org/wp-content/uploads/2017/09/IA_Final_EOA_ report-.pdf

23. Expatriate Ostomates of Spain (EOS) Information Service SPAINCOUNTRY REPORT 2017 by Cynthia Robinson. Available from: https:// ostomyeurope.org/wp-content/uploads/2017/10/Spain_Country_ Report_2017.pdf

24. Turnbull GB. The Ostomy Files: Ostomy Statistics: The $\$ 64,000$ QuestionVolume 49 - Issue 6 - June, 2003 https://www.o-wm.com/ content/ostomy-statistics-the-64000-question siteye ulaşlamıyor

25. Country Report to the European Ostomy Association EOA 2017 Country report 2010 Dutch Ostomy Association Last Accessed Date: https://ostomyeurope.org/wp-content/uploads/2017/02/ NetherlandsCountryReport2010.pdf

26. World Health Organization (WHO) (2016). Colorectal Cancer Estimated Incidence, Mortality and Prevalence Worldwide in 2012. Last Accessed Date: 29.05.2016. http://globocan.iarc.fr/Pages/fact_sheets_cancer.aspx. .

27. 03.03.2020 Sosyal güvenlik Kurumu Sağlik Uygulama Tebliğinde Değişiklik Yapılmasına Dair Tebliğ Sağlık Hizmetleri Fiyatlandırma Komisyonu Kararı Erişiö Adresi: https://www.resmigazete.gov.tr/ eskiler/2020/03/20200303Ml-1.htm

28. T.C. Sağlık Bakanlığı Kamu Hastaneleri Genel Müdürlüğü Finansal Analiz ve Faturalandırma Dairesi Başkanlığ Erişim Adresi: Https:// Khgmfinansalanalizdb.Saglik.Gov.Tr/Tr,40231/Fiyat-Tarifeleri.Html 